\section{Transient global amnesia associated with sildenafil use. Report of one case}

\author{
JOSEF FINSTERER ${ }^{1, \mathrm{a}}$
}

\begin{abstract}
A 69 years old male with erectile dysfunction lasting 2 years, took $50 \mathrm{mg}$ of sildenafil for having sex with his wife at about 6 o'clock in the morning. One hour later his wife detected that he had an anterograde memory impairment: this was interpreted as a confusional state. The neurological examination suggested a transient global amnesia (TGA). EEG and cerebral magnetic resonance imaging were non-informative and memory deficits resolved within $24 \mathrm{~h}$. Therefore, a TGA was diagnosed. Since no other trigger was detectable, sildenafil was deemed responsible for its occurrence,
\end{abstract}

(Rev Med Chile 2019; 147: 527-529)

Key words: Amnesia, Transient Global; Memory; Sildenafil Citrate.

\section{Amnesia global transitoria asociada al uso de sildenafil. Informe de un caso}

Se reporta el caso de un individuo de sexo masculino de 69 años con disfunción eréctil, que ingiere $50 \mathrm{mg}$ de sildenafil con objetivo de facilitar el mantener relaciones sexuales con su esposa. Una hora después, su esposa nota que su marido presenta una alteración de su memoria anterógrada, lo que fue interpretado como un estado confusional. Evaluado clínicamente su examen neurológico es sugerente de una amnesia transitoria anterógrada. El EEG y las imágenes por resonancia magnética no muestran hallazgos significativos y el déficit de memoria remite dentro de 24 h. en vista de su evolución, se diagnostica una amnesia global transitoria. Como no se identifica otro gatillante, se consideró que el cuadro fue causado por sildenafil..

Palabras clave: Amnesia Global; Amnesia Retrógrada; Citrato de Sildenafil.

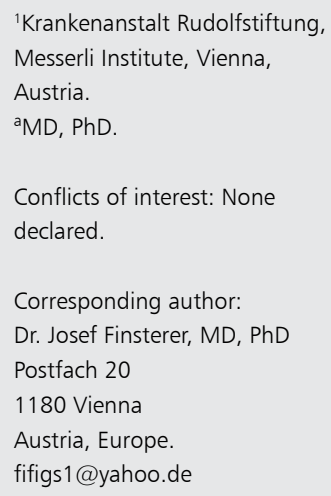

T hough sildenafil, an inhibitor of phosphodiesterase-5, may provide a lot of joy, it may exhibit also a number of disadvantages. Potential side effects of the drug are numerous and concern the central nervous system, the eyes, ears, the endocrine system, the hematological system, the gastro-intestinal tract, the muscle, and the skin. Among the neurological side effects, amnestic syndrome in form a transient global amnesia (TGA) has been only rarely reported ${ }^{1-4}$. Here we report a patient who developed a TGA shortly after intake of sildenafil. The study was carried out according to international ethical standards.

\section{Case report}

The patient is a 69 year old male with a previous history of a colon carcinoma, treated with colonic resection but without requiring chemotherapy or radiation therapy, surgery for a bridle ileus years after the malignancy, prostate hyper- 
trophy, a history of disc prolapse L5/S1, which responded to conservative treatment, erectile dysfunction since 2 years prior to presentation, and a history of a car accident, complicated by rib fractures. He was a previous marathon runner and was still running for $10 \mathrm{~km}$ three times a week. He was not on a regular medication but was occasionally taking sildenafil for impotentia coeundi, which was attributed to adhesions after the bridle ileus.

On the day of presentation he took sildenafil $(50 \mathrm{mg}$ ) for having sex with his wife at about 6 o'clock in the morning. One hour later his wife recognised a confusional state due to memory impairment. Nonetheless, he managed to accompany his two grandchildren to school. After this task, he felt nervous and had difficulties finding back home and required reassurance from his wife via telephone that he has done the right job. He was directed back home successfully and when arriving he was repeatedly asking the same questions and required confirmation that he was behaving properly. He was unable to retain answers to his questions.

Clinical neurologic examination $3.5 \mathrm{~h}$ after onset revealed difficulties recalling recent events. He did not remember what happened in the morning. The Achilles tendon reflex on the right side was reduced being attributed to the disc prolapse years earlier. Blood tests were non-informative, as well as the MRI of the brain and the EEG, recorded $6 \mathrm{~h}$ after the onset of memory impairment. Already $3.5 \mathrm{~h}$ after onset, memory deficits started to resolve. His inability to form new memories lasted altogether 16 hours.

\section{Discussion}

A TGA is defined as a sudden onset episode of memory loss that can't be attributed to epilepsy or stroke ${ }^{5}$. During a TGA recall of recent events vanishes, such that the patient can't remember where he is or how he got there. Additionally, the patient does not remember what's happening in the here and now ${ }^{5}$. Consecutively, the patient keeps repeating the same questions and draws a blank when asked to remember things that happened earlier ${ }^{5}$. Cause and pathogenesis of TGA are unknown but there are indications that ischemia of the hippocampus or the thalamus ${ }^{6}$, migraine, impaired venous drainage from the temporal lobes, seizures, or psychological disturbances ${ }^{7}$ may trigger a TGA. Recently, cytotoxic edema has been detected in the hippocampus of TGA patients ${ }^{8}$ and FDG-PET studies revealed decreased metabolism in the posterior medial network and compensatory increased metabolism in the anterior temporal network ${ }^{9}$. Disturbed perfusion in the hippocampus may not be detectable on visual assessment but by quantitative dynamic susceptibility contrast perfusion $\mathrm{MRI}^{10}$.

In the presented patient sildenafil may have caused constriction of strategic arteries in the hippocampus with consecutive ischemia, which did not result in a visible diffusion or perfusion deficit on multimodal 3T MRI. Sildenafil is the most likely trigger as the history was negative for migraine, cardiovascular risk factors, or emotional stress. There was no indication for a TTS, occasionally associated with a TGA.

This case shows that sildenafil may trigger a TGA in previously healthy individuals. Sildenafil should be used with caution even in apparently healthy and physically fit patients.

\section{References}

1. Marqués-Vilallonga A, Aranda-Rodríguez S, Trallero-Araguás E, Jiménez-Moreno FX. Transient global amnesia associated to sildenafil and sexual activity. Rev Neurol 2014; 59: 93.

2. Shihman B, Auriel E, Bornstien NM. Two cases of transient global amnesia (TGA) following sildenafil use. Harefuah 2006; 145: 656-7.

3. Gandolfo C, Sugo A, Del Sette M. Sildenafil and transient global amnesia. Neurol Sci 2003; 24: 145-6.

4. Savitz SA, Caplan LR. Transient global amnesia after sildenafil (Viagra) use. Neurology 2002; 59: 778.

5. Mayo Clinic Patient and Health Care information. https://www.mayoclinic.org/diseases-conditions/transient-global-amnesia/symptoms-causes/syc-20378531 (accessed in 12/17).

6. Kim BS, Cho SS, Choi JY, Kim YH. Transient global amnesia: a study with Tc-99m ECD SPECT shortly after symptom onset and after recovery. Diagn Interv Radiol 2016; 22: 476-80.

7. Tiu C, Terecoasă EO, Grecu N, Dorobăţ B, Marinescu AN, Băjenaru OA. Transient Global Amnesia After Cerebral Angiography With Iomeprol: A Case Report. Medicine (Baltimore) 2016; 95: e3590. 
8. Ogawa K, Suzuki Y, Akimoto T, Shiobara K, Hara M, Morita A, Kamei S, Soma M. Relationship between Cytotoxicity in the Hippocampus and an Abnormal High Intensity Area on the Diffusion-weighted Images of Three Patients with Transient Global Amnesia. Intern Med 2018; 57: 2631-9.

9. Yi S, Park YH, Jang JW, Lim JS, Chun IK, Kim S. Decreased Metabolism in the Posterior Medial Network with Concomitantly Increased Metabolism in the Anterior Temporal Network During Transient Global Amnesia. Brain Topogr 2018; 31: 468-76.

10. Förster A, Al-Zghloul M, Kerl HU, Böhme J, Mürle B, Groden C. Value of dynamic susceptibility contrast perfusion MRI in the acute phase of transient global amnesia. PLoS One 2015; 10 (3): e0122537. doi: 10.1371/ journal.pone.0122537. 